\title{
COMMENT
}

\section{NOTES ON CONTRACT PROBLEMS AND COMPARATIVE LAW*}

\author{
MaIcolm P. Searp $\dagger$
}

$\mathrm{F}$ IOUR major problems stand first in the list of contract problems ready for study, and perhaps ultimately action, in the light of comimpossibility; the power of a possessor to transfer title to tangible things or contract rights; and specific performance. Many other questions, of course, suggest themselves, such as the defenses of a surety, the protection of a mortgagor, the effect of non-disclosure on a fiduciary's transactions, and the development of contractual rules in the field occupied by technical rules of conveyancing.

$\mathrm{I}$

The doctrine of consideration has, of course, been the subject of elaborate historical and critical study on the part of students and lawyers. If a man simply promises a favorite or particularly needy relative a gift to help him in some work, and then suddenly dies, it may become the duty of his executor or administrator to resist the claim of the promisee; and the abolition of the common law force of the seal in many jurisdictions makes it impossible to make a promise of the sort which shall be binding. If a man seriously promises, even in writing, to keep an offer open for a stipulated time, and the offeree makes elaborate arrangements on the faith of the promise, the offeree cannot nevertheless on that ground insist that the offerer keep his word. If a maker's friend or associate in-

* This memorandum grows out of a course in the comparative law of contracts conducted last spring by Professor Max Rheinstein, with the cooperation of the writer. These notes were prepared as part of an informal exchange of preliminary suggestions between Professor Rheinstein, Mr. Kurt Borchardt, and the writer, in preparation for our work in assembling material for the further study of contract problems in the light of comparative law. The memorandum is, of course, an entirely tentative outline of problems for study, and it is published partly in the hope of securing criticisms and suggestions.

Morris R. Cohen's The Basis of Contract, 46 Harv. L. Rev. 553 (I933) and F. C. Sharp's The Ethics of Breach of Contract, 45 Int. J. Ethics 27 (1934) have furnished some of the philosophical foundation for these notes. The influence of Dean Pound's lectures will be apparent at various points.

$\dagger$ Associate Professor of Law, University of Chicago Law School. 
dorses his note after its delivery to a lending bank and after a loan has been made on the note, for the sake of improving the maker's credit, he cannot nevertheless be relied on by the bank; though if his own note, even fraudulently procured, had been transferred by the borrower merely as security for an antecedent debt, the lender would normally be treated as a holder in due course and entitled to recover accordingly. These are a few of the examples of the questionable justice of rules of the common law which differ from the rules of law applicable to comparable situations in countries whose law has developed from Roman law origins.

The process is familiar by which limitations on the enforcement of simple promises have been removed in the development of the law of continental Europe. The influence of the church and the natural law philosophy in removing limitations of this sort has been particularly emphasized. It is, of course, also to be remembered that the Roman law system did not fill some important commercial needs which began to influence the law in the Middle Ages. Professor Holdsworth's treatment of the history of the bill of exchange is particularly suggestive on this point, and is a reminder that the transactions effected by means of a bill of exchange, even before its negotiation, occasioned even more difficulty for continental lawyers than for English lawyers.

It is to be observed that the medieval English common law contained ideas which, developed logically, would lead to more satisfactory results, in some respects, than the modern common law has achieved. The characteristic formal promise of the common law, the sealed writing, may originally have embodied simply the view that written instruments, properly signed and seriously intended, may create obligations; certainly the abolition of the common law effect of the seal seems to leave defective the law of 'many American jurisdictions. The real obligations of the common law enforced in the actions of account, debt, and detinue, seem to have contained the germs of a development which would have covered at least as wide a field as the real and consensual obligations of the Roman law. The treatment of agency and partnership problems in the action of account, and the treatment of sales by a combination of debt and detinue, are examples of the capacity for progress shown by these actions.

It may be, however, that the idea expressed in these actions has had a limiting effect on the growth of the idea which has created most of the modern law of contract. The promisee who has relied on the representations supposed to be implied in a promise, and who has performed or even promised to perform to his detriment, is the victim of the tort which came to be remedied in assumpsit. The theories of debt and assumpsit 
are, of course, distinct. The surety in the later law is thought of as receiving no quid pro quo, but his obligee may have relied on him to the obligee's detriment; while the promisee for whom another has furnished consideration does not look at all like the victim of a tort and should not on principle recover in assumpsit, though the early cases in account and debt indicate that those remedies should have been available to him. Quid pro quo and consideration may thus supplement each other. On the other hand, the idea that a consideration must be bargained for, apparently related to the idea of quid pro quo, is an obstacle to the logical development of the idea implicit in assumpsit that a recovery should be available to anyone who has, in any selected sense, been hurt by the promise of another and his failure to fulfill it.

The history of Roman law countries and the outline of the medieval common law thus suggest that modern lawyers should consider the desirability of further development in the common law of contract, whether by legislation or decision, or both. There are indeed, as is well known, many indications that the common law of consideration is undergoing a transformation more or less gradual. In the field of gratuitous promises, charitable subscriptions have been enforced in various circumstances by the application of more or less satisfactory reasons. The students of contract and the students of conveyancing will not agree on the reason, but a promise to convey land, followed by possession and lasting improvements by the promisee, is specifically enforced in equity.

In matters less clearly involving gifts, and particularly in some commercial matters, there are striking instances of the enforcement of promises not supported by consideration. A few jurisdictions have treated receipts, particularly written receipts, as operative to effect the discharge of a greater sum on the payment of a smaller. ${ }^{x}$ In the case of another type of promises affecting causes of action, the rules are much better established and even more striking. One may not only "waive" a defense in advance in many situations, but he may even "waive" a defense after it has arisen, as, for example, the rather questionable defense of a surety based on the extension of time to his principal.

Lord Mansfield's efforts to introduce moral consideration had, of course, only very limited success; but some promises of those protected by infancy, bankruptcy, and the Statute of Limitations are enforcible, as well as the promise of one for whom something has previously been done at his request. A curious development of an idea a little like that applied in

× See I7 Iowa L. Rev. 102 (I93I). Cf. Ferry v. Stephens, 66 N.Y. 32I (I876). 
Coggs v. Bernard, ${ }^{2}$ and generally regarded as anomalous, seems to be taking place today. Thus a gratuitous bailee who failed to insure as he promised, and a mortgagee who by a mistake in his application failed to secure effective insurance for his mortgagor, have been held liable in New York. ${ }^{3}$ Even more strikingly, a real estate agent who gratuitously promised to bid for property for his principal has been held liable to the principal on the dubious ground, apparently, that his opportunity to earn a commission is consideration for his promise to bid. ${ }^{4}$ In their discussion of undertaking and hurtful reliance, the opinions in these cases are a reminder of the close relationship between tort and contract. The decisions suggest a development comparable to the history of assumpsit. With the subscription agreements, the promises to convey followed by improvements, and some of the instances of "waiver," they perhaps indicate that the idea of promissory estoppel is likely, as the Restatement indicates, ${ }^{5}$ to be more generally applied by the decisions of the courts.

A number of commercial influences are doubtless producing similar phenomena in various branches of the law. Thus, a pre-incorporation subscription for stock can frequently be regarded as nothing more than an offer to a corporation when formed; and yet in many jurisdictions the offer binds the subscriber on incorporation, without either acceptance by or consideration from the corporation. The result, perhaps, depends on statute. $^{6}$ Again, though directors cannot ordinarily be forced to declare dividends, even if earned, a public declaration of a dividend creates an enforcible right in the stockholders; and the best explanation seems again to be based on promissory estoppel. ${ }^{7}$

Familiar modifications of the ordinary law of contract are to be found in the law of bills and notes, which comes, of course, from the continent. The presumption of consideration is perhaps a trace of the continental origin of this body of law. The rule that a bill or note may be given to release a debt of larger amount in England, or of equal amount in the United States, while explained on various grounds by the judges, seems funda-

${ }^{2}$ I Salk. 26 (1703).

3 Siegel v. Spear, 234 N.Y. 479, I38 N.E. 4I4 (I923); Barile v. Wright, 256 N.Y. I, 175 N.E. 35 I (I93I).

4 Kirby v. Brown, 229 App. Div. I55, 24I N.Y.S. 255 (1930); reversed on other grounds in 255 N.Y. 274 , I74 N.E. 652 (I93 I). For an interesting discussion of these and related cases, see 45 Harv. L. Rev. ${ }^{6} 4$ (I93 $\mathrm{r}$ ).

5 Restatement, Contracts $\S 90$ (I932). See also the cases in which promises in the nature of offers are treated as enforcible on what seem substantially similar grounds. $I d$., $\$ \S 27,45$.

${ }^{6}$ See Page, Contracts $\S_{54 I}$ (2d ed. rg2o). See also 6x A.L.R. $x_{463}$ (rg29).

7 See 28 Mich. L. Rev. $91_{4}$ (1930); 39 Yale L. J. xr63 (x930). 
mentally inconsistent with the supposed requirement that obligations created by a bill or note must be supported by consideration. Even in England, an acceptor may of course be bound to a payee, even though the payee has not furnished the consideration for his obligation. Commercial objections to relieving one who has indorsed after delivery and extension of credit, have led to decisions based on the theory of conditional delivery, where in fact it is very hard to find conditional delivery. Finally, the well-known rule that an obligation created by a negotiable instrument may be voluntarily renounced in writing results from a decision frankly applying continental ideas. ${ }^{8}$

Other examples of tendencies to depart from the strict requirements of consideration have been referred to by various students. The effect of a stipulation in open court is another familiar example of an obligation enforcible without consideration. The instances listed seem the most significant of best established examples of what may be an increasing tendency to depart from the common-law standard of consideration. It is perhaps worth noting that the problem of determining whether a state has undertaken an obligation which will be protected by the contract clause of the constitution may have to be solved without resort to the test of consideration. 9

It may thus be useful to consider changes which can be expected reasonably soon in the doctrines of consideration. The Uniform Written Obligations Act is a suggestion for legislation. It may be that the experience of European lawyers in developing legislation determining the conditions under which promises are enforcible, could be usefully combined with Anglo-American experience, to produce a somewhat more elaborate statute, which would deal more adequately with the variety of cases to which it must apply, and commend itself more to lawyers imbued with AngloAmerican traditions. Such a statute would of course deal separately with gratuitous promises. It would perhaps deal separately with promissory estoppel, perhaps enacting in terms the rules of the Restatement. It would presumably recognize that in a great number of commercial transactions a serious written promise should be enforcible.

It would go a long way in the direction of putting into effect the rule

${ }^{8}$ See Campbell, Cases on Bills and Notes 416-440, 736-739 (I928).

9 Wisconsin Ry. Co. v. Powers, Igr U.S. 379 (I903). See also Newton v. Comm'rs., I00 U.S. 548 (I879); Covington v. Kentucky, I73 U.S. 23 I (I899); Williams v. Wingo, I77 U.S. 60I (rgoo); Rogers Park Water Co. v. Fergus, r80 U.S. 624 (Igor); American Smelting Co. v. Colorado, 204 U.S. ro3 (Igo7); R. R. Comm. v. Eastern Texas Ry., 264 U.S. 79 (I924); Roberts \& Schaefer Co. v. Emmerson, $27 \mathrm{r}$ U.S. 50 (r926); Fort Smith Lighting Co. v. Paving District, 274 U.S. 387 (I927); Abie State Bank v. Bryan, 282 U.S. 765 (I93I). 
frequently stated by the Athenian orators: "Whatever one willingly agrees upon with another shall be sufficient." While it may be that the formula represents a formal Greek promise, the statement is so sensible in terms that it seems well worth remembering. ${ }^{\mathrm{xo}}$

\section{II}

Modification or abolition of the doctrine of consideration would thus make it possible for a promisor voluntarily to confer upon another an asset in the form of a contract right, whose deliberate or negligent or faultless violation may be actionable, and subject to the familiar rules of contract damages. One might voluntarily undertake a risk, and give his promisee a kind of insurance. Since consideration of fault did not begin to be important in the law of torts until the seventeenth century, it is not surprising that comparable considerations have developed only partially in the law of contracts. It seems only consistent, however, with the development in torts, that negligent or faultless mistake of fact should develop significance in the law of contracts. It would not be surprising, indeed, to find that one whose foresight was confused by any substantial mistake of fact, even as the result of negligence, is liable at most for expenses occasioned his promisee as the result of his undertaking and failure to make it good.

The Anglo-American law, like other bodies of law, has, of course, not developed consistently to any such point. In cases of mutual mistake, a variety of tests for relief have been attempted; and the one which seems to be getting general acceptance represents, perhaps, some improvement over the Roman law test. The rule that relief will be granted for mistake as to an essential characteristic of a person, thing, or transaction, while it may be applied to reach sound results, seems open to some objection. Is a mistake as to the nature of soil a mistake as to an essential quality of a thing? If so, do the classifications in treatises on soils control the courts? Can the question be determined at all by physical considerations? Must not the "subjective" mental states of the parties have considerable weight? If "subjective" states are dealt with by a concept of assumption of risk, does not the consideration of essential qualities become subordinate, and at best, of slight help in the application of some other controlling principle? Much the same difficulties can be raised with efforts to distinguish between mistakes as to "extrinsic" and "intrinsic," or "collateral" and "material" facts. In some situations the application of such tests would, if taken seriously, result in improper relief for mistake; while in

ro See Weiss, Griechisches Privatrecht $43^{\mathrm{I}-433}$ (I923). 
other cases, for example cases of mistake about the assets behind securities, such tests might unduly limit relief.

Accordingly, the "fundamental assumption" test seems to be gaining favor among American students and courts. The chief objection to this test is, of course, that it is simply a vague set of terms by which the results of a kind of administrative justice can be labeled. It seems possible, however, to give the test sufficient content so that it will be useful as a guide or standard in the ordinary work of the courts. Thus, where the parties to a transaction think of a fact as humanly certain, that is, possessing very high probability, and as a result make their transaction; and it is impossible to suppose that they were taking the risk of circumstances turning out otherwise, the mistake, if prejudicial, will be a defense to a contract action or suit, or a ground for affirmative relief. Because of interests in promised advantages, property, the security of transactions and acquisitions; in recognition of conditions of trade, and the understanding of businessmen; and with a view to consistency with the perhaps debatable fundamental elements of our theory of "objective" consent and contract damages, parties will be treated as taking the risk of all circumstances as to which their position seems doubtful to the trier of the mixed question of fact and law presented. For a mutual mistake, both parties must make the same assumption and perhaps recognize that it controls their conduct.

The development of such a test would perhaps represent an improvement over the rather special treatment of different kinds of mistake found in some bodies of European law. It should perhaps be supplemented by special rules as to mistake of expression. Peculiar considerations perhaps apply, further, to mistake in situations not complicated by the existence of transactions which would normally be recognized as effective by courts, such as mistakes resulting from the activities of supposed agents and mistakes in the performance of contracts. In these cases the security of transactions is not seriously in question, and relief should therefore be more readily granted.Ix It may be, however, that the suggested test and principle cover all these situations adequately.

The Anglo-American law of mistake could perhaps most profitably be improved by the addition of foreign elements in dealing with unilateral mistake, mistake of law, and the apportionment of losses resulting from mistake.

While relief for unilateral mistake of expression seems likely to be given

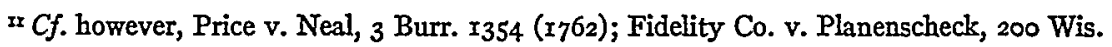
304, 227 N.W. 387 (I929). 
increasingly, relief for unilateral mistake of other sorts is not in favor with either writers or courts. It seems not unlikely that the situation is partly the result of the concentration of attention on unilateral mistakes of calculation in the bids of contractors. Relief for mistake of this sort is not given in Germany, where relief for unilateral mistake of other sorts is common. The result is due to the wording of the German Code in its treatment of mistake as to essential qualities. It seems, however, that the result may arguably be justified on a principle which should apply in any system in which relief for unilateral mistake is granted. It may be that a contractor must ordinarily assume the risk of the accuracy of his figures. The American opinions dealing with this situation may be thus for the most part sound. On the other hand, their discussion of unilateral mistake perhaps goes beyond the necessities of the cases, and it seems inconsistent with the principle on which relief for mistake of any sort is granted.

The principle may perhaps be stated somewhat in this way. Where mistake is recognized as a defense to an executory contract, a "subjective" element appears in the law of contracts. An obligee who can secure the return of his consideration or its equivalent and has not, except by furnishing the consideration changed his position, is not "wronged" by the mistaken obligor's refusal to perform. Indeed, as has been observed, damages for the consequences of fault in contracting should perhaps logically be the limit of recovery in any case against an obligor who is negligently or faultlessly mistaken. A strong interest in the security of transactions, and as well, perhaps, a metaphorical development of substance or thing concepts of contract, are perhaps the explanation of the familiar rules of contract damages. A negligently mistaken obligor who deliberately refuses to perform seems much like the negligent author of a misrepresentation who deliberately refuses to make good. The limits of the liability of such a person have, of course, been much discussed.

In the case of mistake in an executed transaction, since failure to perform would not have been a wrong, objections based on the security of transactions fail, and affirmative reasons for relief appear. In such cases, and in cases where mistake appears apart from contract, the controlling interests seem analogous to individual interests of property and general interests in the security of acquisitions. Comparable considerations occur in cases of negotiorum gestio; here, however, these interests to prevail must be combined with other interests, in the Anglo-American law. In cases where property has been transferred by mistake, the individual interests of property and the general interests in security of acquisitions themselves 
appear in a clear light, operating to create a rule protecting the original owner from something like the "loss" of things against a "finder" who "wrongfully," without justification, insists on the uncompensated retention of "accidentally acquired" (not "deliberately given") benefits, to the original owner's hurt. ${ }^{12}$ As has just been suggested, a closely comparable set of considerations applies to the cases where services have been rendered, or interests in "intangibles" created, by mistake.

If these suggestions as to the principle controlling relief for mistake are at all sound, it seems to follow that relief for unilateral mistake should be given subject to the same limitations which apply in case of mutual mistake.

Moreover, it would seem to follow, also, that relief for mistake of fact should be given no more readily than relief for mistake of law. It is perhaps true that in many cases of mistake of law, the parties must be treated as assuming the risk of mistake, according to the standard which has been suggested..$^{23}$ On the other hand, this observation suggests caution in the application of the principle, not a refusal to apply it to mistakes of law. An interesting case of relief for unilateral mistake of law, which seems not adequately explained by the court's suggestion of the taking advantage of a known mistake, perhaps indicates the direction which Anglo-American courts will increasingly follow. ${ }^{14}$

Finally, the continental treatment of mistake suggests a reasonable treatment of the problem of apportioning losses resulting from mistake. If relief is allowed for unilateral mistake, a person seeking relief should not be defeated because of a change of position, but should be required to compensate the other party for any loss resulting from either faultless or negligent mistake. Similarly, it seems in cases of mutual mistake relief should not be denied because of change of position, but any loss should either be shared equally or in proportion to any blame or responsibility which can be attributed to either party. The result may, of course, be a denial of any relief in a considerable number of the cases in which change of position makes it impossible to apportion loss. In other cases, however, a development of the rules governing relief for fraud may be useful in suggesting rules for apportioning losses and determining the necessity for restitution in cases of mistake.

${ }^{12}$ See the opinion of Lord Sumner in Jones v. Waring and Gillow, [1926] A.C. 670.

${ }^{{ }_{3}}$ See 45 Harv. L. Rev. 336 (I93I).

${ }_{44}$ Peterson v. First Nat'l Bank of Ceylon, I62 Minn. 369, 203 N.W. 53 (I925). And see Thayer, Unilateral Mistake and Unjust Enrichment as a Ground for the Avoidance of Legal Transactions, Harvard Legal Essays, 467, 499 (I934). 
A number of minor points may require special consideration. It seems that innocent misrepresentation should make it more difficult for a person resisting relief to rely on assumption of risk by the other party; in this respect, the German rule seems subject to improvement in the light of the American decisions. The peculiar treatment of misunderstanding, or latent dissent, resulting from the considerations controlling the decision of Raffles $v$. Wichelhaus, ${ }^{\text {,5 }}$ should perhaps be further considered, particularly in its application to cases of unilateral misunderstanding. It is not indeed apparent that those rare cases in which mistake prevents the existence of a transaction at law, should be treated any differently from the cases in which relief for mistake has either developed in equity or been influenced by equitable principles applied by courts of law. Unilateral palpable mistake should receive special consideration. It would perhaps be relatively easy to establish a similarity between mistake of expression and mistake as to the legal consequences of words, the type of mistake of law for which relief is most commonly granted in America.

Finally, it seems doubtful whether the rule that mistakes in writing can be reformed only in equity and are therefore to be dealt with only by the court and not the jury under a code, is justified by practical considerations outweighing the resulting confusion in those jurisdictions where the preservation of the distinction is not required by the interpretation of a constitution. It should indeed be considered whether the rule, if it applies to reformation, does not in principle equally apply to any relief for mistake in a transaction embodied in a writing.

Principles applicable to mistake are, as has often been observed, closely comparable to the principles applicable to impossibility. It seems likely that a consideration of mistake will prepare for the sound development of greater liberality in granting relief for impossibility in the American courts. In this development, it seems possible that American lawyers will derive considerable help from recent experience in Germany.

\section{III}

Individual responsibility for voluntary undertakings and liability for fault seem to be ideas which are capable of further development in the rules governing consideration and mistake. The same ideas will perhaps require further development in the treatment of negotiability and related phenomena.

It is rather striking that the first important decision on the protection of private rights afforded by the constitution dealt with the rights of a

${ }^{15} 2$ H. \& C. 906 (1864). 
bona fide purchaser from a fraudulent grantee of land. ${ }^{16}$ An exploration of the reasons given by courts of equity for protecting bona fide purchasers may throw some light on the general theory of negotiability. A notable limitation on the protection given bona fide purchasers in equity results from the application of the maxim that of two equities, the prior in time prevails; and particularly from the application of this principle to rights in choses in action. The limitation was questioned in a classic article. ${ }^{17}$ An application of the limitation was further examined more recently in a study of rights in overdue negotiable instruments. ${ }^{18}$

The common opinion is that recording acts do not create anything comparable to the negotiability of interests in real estate. ${ }^{x 9}$ Compare, however, the language in an opinion of Mr. Justice Holmes sustaining the validity of a Torrens system against constitutional attack. ${ }^{20}$ And the negotiability of mortgage interests securing negotiable instruments is a familiar phenomenon.

It seems possible that a primitive negotiability of chattel interests was destroyed by a not very well considered development of the action of detinue. ${ }^{2 x}$ It is striking that German ideas were displaced by Roman ideas in English history; while on the continent, Roman ideas have been replaced by a limited negotiability of chattel interests. It seems not unlikely that commercial necessities require a revival of something like some primitive German ideas. The most familiar example of the pressure of commercial necessity in this direction is the development of the Factors' Acts. A tendency to extend the apparent authority of the bailee appears in the paradoxical rule that while his possession does not of itself give him apparent authority to sell, yet possession accompanied with authority to sell on named terms gives effective power to sell on other terms, and possession accompanied with authority to mortgage on named terms gives the power effectively to mortgage on other terms..2 The rules governing the power of a seller who retains possession and the seller who makes no delivery, though based on theories of fraudulent transfer, seem to suggest the possibility of the emergence of a new general principle. ${ }^{23}$ The negotiability of (I933).

${ }^{16}$ See the writer's Movement in Supreme Court Adjudication, 46 Harv. L. Rev. 361, 365

${ }^{17}$ See Ames, Purchaser for Value without Notice, I Harv. L. Rev. I (r887).

${ }^{18}$ See Chafee, Rights in Overdue Paper, 3 I Harv. L. Rev. IIo4 (IgI8).

${ }^{19}$ See Aigler, The Operation of the Recording Acts, 22 Mich. L. Rev. 405 (r924).

so Eliason v. Wilborn, 28r U.S. 457 (x929).

2x See Waite, Caveat Emptor and the Judicial Process, 25 Col. L. Rev. 129 (1925).

${ }^{2}$ See 42 Harv. L. Rev. 685 (r929).

${ }^{23}$ See Williston, Sales $\S \S 310-325,349-404$ (2d ed. I924). 
chattels by means of bills of lading is a more striking recent development in the law.

Principles which may enlarge the power of one entrusted with possession to make a good title to a bona fide purchaser may be expected also to enlarge the field of negotiable promises, and perhaps as well to facilitate the negotiation of negotiable instruments by other means than the traditional commercial indorsement..24 A comparable development is to be found in the case of some other instruments like insurance policies, which are commonly associated in the business mind with the obligations which they represent. ${ }^{25}$

The "objective" theory of contract seems to require a recognition of a power in the possessor of a chattel, or an instrument associated in the commercial mind with its obligation, greater than that which Anglo-American courts have been disposed to recognize. Moreover, it has not been suffciently observed that the strict rules of conversion involve an application of liability without fault which seems inconsistent with much of the rest of our tort law..$^{26}$ On consideration, it is perhaps less paradoxical than it seems to suppose that the development of industry may require the extension of liability without fault in such cases as those dealt with by Rylands v. Fletcher, ${ }^{27}$ and in the fields of industrial and automobile accidents; while at the same time the increasing complexity of commerce may require a limitation of the liability or loss of a person who reasonably or merely in good faith purchases chattel or contract rights from one who has been entrusted with the possession of what in ordinary life passes as evidence of title.

A consideration of the tort question by itself might lead also to protection of a bona fide purchaser from a thief. Here, however, the policy considerations seem more difficult to weigh, and the principles of contract

${ }^{24}$ For an introduction to the extensive discussion of this question, see Sinykin, Extension of the Concept of Negotiability, 8 Wis. L. Rev. 272 (1932). Compare the much criticized but perhaps correct case of Marling v. Fitzgerald, 138 Wis. 93 ( $x(909)$. An increasing recognition that these principles are "normal" will perhaps help in determining the effect of some kinds of "restrictive indorsements." Compare Gulbranson-Dickinson Co. v. Hopkins, I7o Wis. 326, I75 N.W. 93 (I9I9). It may suggest further reconsideration of the effect of forged indorsements in some situations. See Hudson and Feller, The International Unification of Laws Concerning Bills of Exchange, 44 Harv. L. Rev. 333, 354-355, 360-36I (I93I).

${ }^{25}$ See Campbell, Cases on Bills and Notes 58I (r928), note 3 , for an introduction to the references on this point.

${ }^{26}$ Cf. Hollins v. Fowler, L.R. 7 H.I. 757 ( 1875$)$. ${ }^{27}$ L.R. 3 H.L. 330 (1868). 
offer no help. The purchaser from a bailee has been dealt with more favorably than the purchaser from a thief, both in European law and in our own law..$^{28}$

\section{IV}

The fourth subject which seems ready for consideration is the subject of specific performance. Here the influence of historical circumstances on our law is again strong; though the practical importance of the resulting situation should again not be exaggerated.

The influence of personalities in the development of the equitable principles governing specific performance is in two or three instances rather striking. The intemperance of Lord Chancellor Jefferies, which appears in Lord Campbell's life of Jefferies, is exemplified in his first decision that the taking of possession of land might take a land contract out of the Statute of Frauds. ${ }^{29}$ Here the scope of relief was broadened. On the other hand, Professor Page has suggested that the limits on specific performance, based on the supposed difficulty of supervising affirmative conduct, may have resulted from the easy-going habits of some English chancellors. ${ }^{30}$ In enforcing a trackage contract, Chief Justice Fuller once spoke of "the intolerable travesty of justice involved in permitting parties to refuse performance of their contracts at pleasure by electing to pay damages for their breach." ${ }_{31}$ Lord Justice Fry's enthusiasm for Aristotle, Kant, and particularly Bishop Joseph Butler (see his "Sermons on Human Nature") may possibly explain, though it does not warrant, his interest in his rather abstract and formal doctrine of mutuality. ${ }^{32}$

These limits on the availability of specific performance are perhaps disappearing. A more important limit which makes it impossible for a farmer to secure the specific performance of a contract for the purchase of an ordinary herd of cattle, and for a city person to secure specific performance of a contract for the purchase of stock without wasting time in argument as to its uniqueness, remains.

It may be that the effort made in the Uniform Sales Act to liberalize the availability of the remedy has met an obstacle in fear of the consequences

${ }^{28}$ Compare Chafee, Rights in Overdue Paper, 3I Harv. L. Rev. IIo4 (IgI8). On this third group of problems, see particularly Harvey, The Victims of Fraud (r932).

29 Butcher v. Stapley, I Vern. $3^{63}$ (I685).

${ }^{30}$ See 6 Page, Contracts $\$ 3354$ (2d ed. $x 922$ ).

${ }^{3 t}$ Union Pacific Railway Co. v. Chicago Railway Co., I63 U.S. 564, 600 (I896).

${ }^{32}$ See Agnes Fry, Memoirs of Sir Edward Fry 158, I59 (I92I); F. C. Sharp, Ethics, 300302, 306-32I (1928). 
of the extended application of principles of equitable conversion to chattel interests. ${ }^{33}$ It may be that a party to a contract should be protected against the sale of the subject-matter to any purchaser with notice. ${ }^{34}$ On the other hand, the law of sales sufficiently covers the transfer of chattel interests, and should not be complicated by ideas of equitable conversion by contract. In particular, the interests of creditors who rely in good faith on the state of legal title resulting from the ordinary rules of sales and mortgages should not be endangered by the extension of the right to specific performance. A statute extending specific performance should be so drafted as clearly to protect the interests under discussion.

33 Compare Bowman v. Adams, 45 Idaho 217, 26r Pac. 679 (I927).

${ }^{34}$ Compare Minnesota Marketing Assn. v. Radke, $x_{3}$ Minn. 403 , 204 N.W. $3{ }^{14}$ (r925); Liberty Co. v. Burley Assn., 276 U.S. $7 x$ (r928). Kelley v. Central Hanover Bank and Trust Co., Ir F. Supp. 497 (N.Y. I935), decided since this was written, illustrates the problems under discussion. 